\title{
THE SYNTHESES OF THE MARINE METABOLITES 3-BROMOVERONGIAQUINOL AND 5-MONOBROMOCAVERNICOLIN"
}

\author{
Luiz Antonio Fonseca de Godoy and Ronaldo Aloise Pilli* \\ Instituto de Química, Universidade Estadual de Campinas, CP 6154, 13083-970 Campinas - SP, Brasil
}

Recebido em 5/5/10; aceito em 27/6/10; publicado na web em 18/10/10

\begin{abstract}
An efficient synthesis of the marine metabolite 3-bromoverongiaquinol (1) and the first total synthesis of 5-monobromocavernicolin (2), both isolated from the marine sponge Aplysina cavernicola, have been described based on the 1,2 addition of the lithium enolate of $\mathrm{N}, \mathrm{O}$-bistrimethylsilylacetamide (BSA, 4) to 1,4-benzoquinone (3). Bromination and purification of the crude product on silica gel chromatography provided 3-bromoverongiaquinol (1) in 50\% overall yield. Under alkaline conditions, the crude product of the bromination reaction was converted to 5 -monobromocavernicolin (2) in 20\% yield which was also obtained in 13\% yield (25\% yield based on recovered starting material) from 3-bromoverongiaquinol (1).
\end{abstract}

Keywords: Aplysina cavernicola; 3-bromoverongiaquinol and 5-monobromocavernicolin; synthesis.

\section{INTRODUCTION}

The invertebrates are the main source of biologically active natural compounds among marine organisms. Over the last 25 years, sponges have been a privileged research topic due to the large number of biologically active metabolites produced by the gender Porifera. ${ }^{1}$ These metabolites are part of the chemical arsenal employed by these organisms against predators or to mark their territory. ${ }^{2}$ Verongida sponges attract the attention of chemists and biologists as natural sources of unusual fatty acids, ${ }^{3}$ steroids, ${ }^{4}$ carotenoids ${ }^{5}$ and aminoacids. ${ }^{6}$ For example, from Aplysina cavernicola several biologically active compounds such as 3-bromoverongiaquinol $(\mathbf{1})^{7}$ and 5-monobromocavernicolin $(2)^{8}$ have been isolated. In 2002, compound $\mathbf{2}$ was also obtained from another marine sponge (Suberea aff. praetensa). ${ }^{9}$<smiles>NC(=O)C[C@]1(O)C=CC(=O)C(Br)=C1</smiles>

$(+/-)-1$

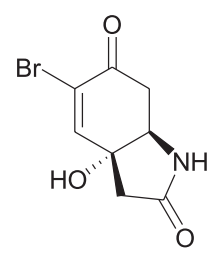

$(+/-)-2$
Figure 1. Marine metabolites (+/-)-1 and (+/-)-2

While 3-bromoverongiaquinol (1) displayed bactericidal properties against Streptococcus faecalis and Bacillus subtilis, ${ }^{7}$ 5-monobromocavernicolin (2) represents the first example of a marine natural product isolated in almost racemic form (6\% ee) which was shown to inhibit the growth of Sarcina lutea, Bacillus subtilis, Alcaligenes faecalis and Proteus vulgaris. ${ }^{8}$

Racemic 3-bromoverongiaquinol (1) has been previously prepared twice via anodic oxidation, albeit in very low yields ( 2.5 and $6.3 \%$ yield), ${ }^{7,10}$ and the relative configuration of 5-monobromocavernicolin (2) was proposed based solely on spectroscopic and mass spectrometry data as no total synthesis has been reported so far. ${ }^{8}$

*e-mail: pilli@iqm.unicamp.br

"This paper is dedicated to Prof. Hans Viertler
We were attracted to the synthesis of compounds $\mathbf{1}$ and $\mathbf{2}$ not only because the biological profile of 5-monobromocavernicolin (2) remains unexplored, but also because these two compounds may reasonably be biogenetically interconnected as (+/-)-2 might conceivably be formed via a 1,4-addition of the amide group to the less hindered conjugated double bond in (+/-)-1. Therefore, it was our expectation at the onset of this work to contribute with a synthetic route to both 3-bromoverongiaquinol (1) and 5-monobromocavernicolin (2).

\section{RESULTS AND DISCUSSION}

The synthesis of compounds $\mathbf{1}$ and $\mathbf{2}$ was envisaged starting with the 1,2-addition of the lithium enolate derived from $N, O$-bistrimethylsilylacetamide (BSA, 4) to 1,4-benzoquinone (3) (Scheme 1). Our first attempt was based on an analogous transformation reported by Evans and coworkers: ${ }^{11}$ after generation of the lithium enolate of BSA (4) in THF at $-78^{\circ} \mathrm{C}$, the addition of 1,4-benzoquinone (3) was carried out at $-100{ }^{\circ} \mathrm{C}$, to afford a mixture of silyl amide $\mathbf{5}$ (28\% yield) and amide 6 (5\% yield) after warm up to $0{ }^{\circ} \mathrm{C}$, aqueous acid treatment and purification by chromatography on silica gel (Table 1, entry 1 )

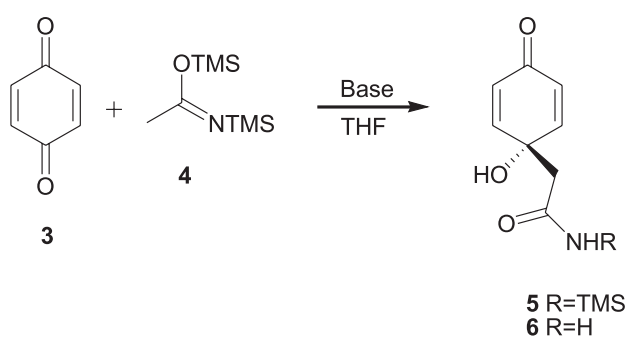

Scheme 1. Preparation of amides 5 and 6

By increasing the reaction temperature to room temperature after the addition of 1,4-benzoquinone (3) to the lithium enolate of BSA (4) at $-100{ }^{\circ} \mathrm{C}$, the combined yield of amides $\mathbf{5}$ and $\mathbf{6}$ increased to $36 \%$ with amide $\mathbf{6}$ as the major product (Table 1, entry 2). The addition of DMPU or HMPA did not prove to be beneficial (Table 1, entries 3 and 4 ) and the use of the sodium enolate of BSA provided neither amide $\mathbf{5}$ nor $\mathbf{6}$ (Table 1, entry 5). The best combined yield of amides 5 and $\mathbf{6}(56 \%)$ was achieved by employing 2.0 equiv. of the lithium enolate of BSA and reaction temperature ranging from $-100{ }^{\circ} \mathrm{C}$ to $\mathrm{rt}$, 
which afforded amide $\mathbf{6}$ as the major product in $38 \%$ yield accompanied by silyl amide $\mathbf{5}$ in $18 \%$ yield, after column chromatography on silica gel (Table 1, entry 6).

Table 1. Reaction conditions and yields for amides 5 and $\mathbf{6}$

\begin{tabular}{lcccccc}
\hline Entry & Base & BSA (equiv.) & Temperature & Additive & $\mathbf{5}(\%)$ & $\mathbf{6}(\%)$ \\
\hline 1 & LDA & 1.0 & $-100{ }^{\circ} \mathrm{C}$ to $0{ }^{\circ} \mathrm{C}$ & - & 28 & 5 \\
2 & LDA & 1.0 & $-100{ }^{\circ} \mathrm{C}$ to rt & - & 4 & 32 \\
3 & LDA & 1.0 & $-100{ }^{\circ} \mathrm{C}$ to rt & DMPU & 6 & 25 \\
4 & LDA & 1.0 & $-100{ }^{\circ} \mathrm{C}$ to rt & HMPA & 5 & 12 \\
5 & NaHMDS & 1.0 & $-100{ }^{\circ} \mathrm{C}$ to rt & - & - & - \\
6 & LDA & 2.0 & $-100{ }^{\circ} \mathrm{C}$ to rt & - & 18 & 38 \\
\hline
\end{tabular}

We next investigated the bromination reaction of amides $\mathbf{5}$ and $\mathbf{6}$ in order to achieve the preparation of 3-bromoverongiaquinol (1). Despite being only partially soluble in $\mathrm{CHCl}_{3}$, each amide reacted with bromine at $0{ }^{\circ} \mathrm{C}$ to $\mathrm{rt}$ via the dibromo derivative (+/-)-7, as revealed by ${ }^{1} \mathrm{H}-\mathrm{NMR}$ data of the crude mixture, to afford, after column chromatography on silica gel, 3-bromoverongiaquinol (1) in reasonable overall yield $(67 \%)$ in both cases. Acetonitrile proved to be the best solvent and, after the same sequence of steps, both amides $\mathbf{5}$ and $\mathbf{6}$ provided 3-bromoverongiaquinol (1) in 89\% overall yield (Scheme 2).<smiles>NC(=O)CC1(O)C=CC(=O)C=C1</smiles><smiles>NC(=O)C[C@]1(O)C=CC(=O)C(Br)C1Br</smiles>

$(+/-)-7$ $5 \mathrm{R}=\mathrm{TMS}$<smiles>NC(=O)C[C@]1(O)C=CC(=O)C(Br)=C1</smiles>

$(+/-)-1$ $6 \mathrm{R}=\mathrm{H}$

Scheme 2. Synthesis of (+/-)-3-bromoverongiaquinol (1)

To explore the preparation of 5-monobromocavernicolin (2) directly from silyl amide 5 and amide $\mathbf{6}$ (Scheme 3), their bromination products were treated with LDA but (+/-)-5-monobromocavernicolin (2) was isolated in low yield both from silyl amide $\mathbf{5}$ and from amide 6 (Table 2, entries 1 and 2). The same poor result was observed when (+/-)-6 was treated with NaHMDS in THF (Table 2, entry 3). When the bromination products of amides $\mathbf{5}$ and $\mathbf{6}$ were treated with tertBuOK, only (+/-)-1 was obtained in $74 \%$ yield from both amides.

In all these attempts to obtain (+/-)-2 via the brominationdehydrobromination-1,4-addition sequence the main product was always (+/-)-3-bromoverongiaquinol (1). These results clearly pointed out that the use of a strong base was not appropriate to promote the requisite 1,4 -addition, probably due to the reversible nature of this addition under strongly basic conditions. Then, we turned our attention to the use of DBU, a weaker base which is known to promote dehydrobromination to generate unsaturated ketones. ${ }^{12}$ In fact, after bromination of silyl amide (+/-)-5 in $\mathrm{CH}_{3} \mathrm{CN}$ at $0{ }^{\circ} \mathrm{C}$, treatment of the crude product with 1.0 equiv. of DBU provided (+/-)-2 in $20 \%$ overall yield (Table 2, entry 4 ) with (+/-)-1 as the major product (47\% yield).

Finally, we explored the formation of 5-monobromocavernicolin (2) from 3-bromoverongiaquinol (1) by treating the latter compound in $\mathrm{CH}_{3} \mathrm{CN}$ with 1.0 equiv. of DBU (Scheme 4). The reaction provided $(+/-)-2$, in $13 \%$ yield ( $25 \%$ based on recovered starting material), and its regioisomer (+/-)-8 (25\% yield). In spite of the competitive formation of $(+/-)-8$, this result demonstrates the feasibility of the conversion of (+/-)-1 to (+/-)-2 under basic conditions.

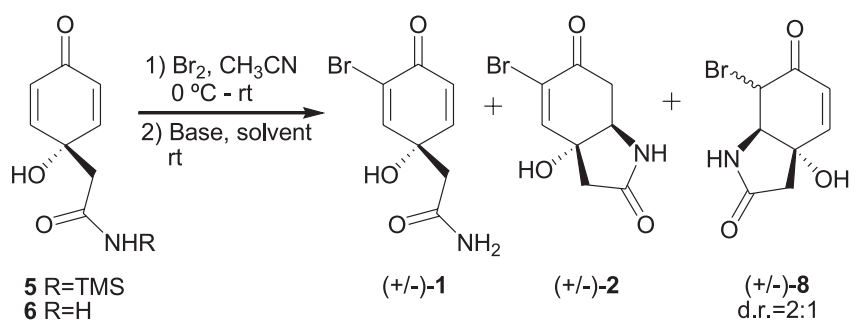

Scheme 3. Synthesis of (+/-)-5-monobromocavernicolin (2) and lactam (+/-)-8

Table 2. Cyclization products derived from amide $\mathbf{5}$ and $\mathbf{6}$

\begin{tabular}{lcccccc}
\hline Entry & $\mathrm{R}$ & $\begin{array}{c}\text { Base } \\
\text { (equiv.) }\end{array}$ & Solvent & $\begin{array}{c}(+/-)-\mathbf{1} \\
(\%)\end{array}$ & $\begin{array}{c}(+/-)-\mathbf{2} \\
(\%)\end{array}$ & $\begin{array}{c}(+/-)-\mathbf{8} \\
(\%)\end{array}$ \\
\hline 1 & $\mathrm{H}$ & LDA (1.0) & THF & 45 & 4 & 22 \\
2 & TMS & LDA (3.0) & THF & 23 & 5 & 12 \\
3 & $\mathrm{H}$ & NaHMDS (1.0) & THF & 55 & 3 & 6 \\
4 & TMS & DBU (1.0) & $\mathrm{CH}_{3} \mathrm{CN}$ & 47 & 20 & 10 \\
\hline
\end{tabular}

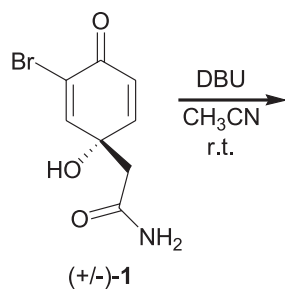

$(+/-)-1$

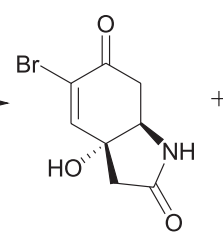

$(+/-)-2$<smiles>O=C1C[C@]2(O)C=CC(=O)[C@@H](Br)[C@H]2N1</smiles>

$(+/-)-8$

d.r. $=2: 1$
Scheme 4. Synthesis of (+/-)-5-monobromocavernicolin (2) from 3-bromoverongiaquinol (1)

Synthetic 5-monobromocavernicolin (2) displayed spectroscopic (IR, ${ }^{1} \mathrm{H}$ - and ${ }^{13} \mathrm{C}-\mathrm{NMR}$ ) and mass spectrum data identical to those reported by Pietra and coworkers ${ }^{8}$ for natural 5 -monobromocavernicolin (2), thus confirming the assignment of its relative configuration.

\section{EXPERIMENTAL}

\section{Instrumentation}

${ }^{1} \mathrm{H}-\mathrm{RMN}$ and ${ }^{13} \mathrm{C}-\mathrm{RMN}$ were record on a Varian Gemini instrument operating at 300 and $75 \mathrm{MHz}$, respectively, or on a Varian Inova instrument operating at 500 and $125 \mathrm{MHz}$, respectively. Infrared spectra were obtained with a Thermo Nicolet IR-200 instrument. Mass spectra were measured on a VG Autospec instrument using EI technique at $70 \mathrm{eV}$ or on a QTof Ultima Waters using ESI technique.

\section{2-(1-Hydroxy-4-oxo-2,5-cyclohexadienyl)- $N$-trimethylsilyl acetamide (5) / 2-(1-hydroxy-4-oxo-2,5-ciclohexadienyl) acetamide (6)}

To a flask equipped with a magnetic stirring bar, under argon atmosphere and at $-78{ }^{\circ} \mathrm{C}$ was added diisopropylamine $(0.20 \mathrm{~mL}$, $1.41 \mathrm{mmol})$ and THF (12.0 mL). To this solution was added $n$-BuLi (2.35 M soln. in hexanes, $0.60 \mathrm{~mL}, 1.41 \mathrm{mmol}$ ) and after stirring 5 min at $-78^{\circ} \mathrm{C}, \mathrm{N}, \mathrm{O}$-bistrimethylsilylacetamide (BSA, $0.70 \mathrm{~mL}, 2.82$ mmol) was added and stirring was maintained for $30 \mathrm{~min}$ at the same temperature. The reaction mixture was cooled to $-100^{\circ} \mathrm{C}$ for the addition of a soln. of 1,4-benzoquinone $(0.152 \mathrm{~g}, 1.41 \mathrm{mmol})$ in THF (5.0 $\mathrm{mL}$ ) and the reaction mixture was kept at $-78^{\circ} \mathrm{C}$ for $3 \mathrm{~h}$. The reaction 
mixture was warmed up to rt, satd. $\mathrm{NH}_{4} \mathrm{Cl}$ soln. was added and after drying over $\mathrm{MgSO}_{4}$ and filtration through a pad of Celite, the solvent was removed under reduced pressure. After column chromatography on silica gel (ethyl acetate as eluent), 5 (0.062 g, $0.26 \mathrm{mmol})$ was obtained in $18 \%$ yield as a white solid ( $\left.\mathrm{mp} 101-103^{\circ} \mathrm{C}\right)$ and $\mathbf{6}(0.091$ $\mathrm{g}, 0.54 \mathrm{mmol})$ in $38 \%$ yield as a white solid $\left(\mathrm{mp} 114-115^{\circ} \mathrm{C}\right)$.

Analytical data for 2-(1-Hydroxy-4-oxo-2,5-cyclohexadienyl)-Ntrimethylsilyl acetamide (5): IR (neat, $\mathrm{cm}^{-1}$ ): 3359, 2952, 1682, 1404, 1072 and $845 .{ }^{1} \mathrm{H}-\mathrm{NMR}\left[300 \mathrm{MHz},\left(\mathrm{CD}_{3}\right)_{2} \mathrm{CO}\right)$ ]: $\delta 7.19(2 \mathrm{H}, \mathrm{d}, J 10.3$ $\mathrm{Hz}), 6.88$ (1H, br s), $6.40(1 \mathrm{H}$, br s), $6.16(2 \mathrm{H}, \mathrm{d}, J 10.3 \mathrm{~Hz}), 2.58$ $(2 \mathrm{H}, \mathrm{s})$ and $\left.0.13(9 \mathrm{H}, \mathrm{s}) .{ }^{13} \mathrm{C}-\mathrm{NMR}\left[75 \mathrm{MHz},\left(\mathrm{CD}_{3}\right)_{2} \mathrm{CO}\right)\right]: \delta 185.0$, 170.0, 151.6, 127.7, 70.5, 48.8 and 1.5. HRMS (70 eV, $\mathrm{m} / \mathrm{z})$ : calcd. for $\mathrm{C}_{11} \mathrm{H}_{17} \mathrm{NO}_{3} \mathrm{Si}-\mathrm{M}^{++} 239.09777$; found: 239.09711 .

Analytical data for 2-(1-hydroxy-4-oxo-2,5-ciclohexadienyl) acetamide (6): IR (neat, $\mathrm{cm}^{-1}$ ): 3359, 2929, 1660, 1622, 1402 and 1032. $\left.{ }^{1} \mathrm{H}-\mathrm{NMR}\left[300 \mathrm{MHz},\left(\mathrm{CD}_{3}\right)_{2} \mathrm{CO}\right)\right]: \delta 7.23(1 \mathrm{H}, \mathrm{br} \mathrm{s}), 7.04(2 \mathrm{H}$, d, $J 10.3 \mathrm{~Hz}), 6.80(1 \mathrm{H}$, br s), $6.10(1 \mathrm{H}, \mathrm{d}, J 10.3 \mathrm{~Hz}), 5.90(1 \mathrm{H}, \mathrm{s})$ and $2.61(2 \mathrm{H}, \mathrm{s}) .{ }^{13} \mathrm{C}-\mathrm{NMR}$ [75 MHz, $\left.\left.\left(\mathrm{CD}_{3}\right)_{2} \mathrm{CO}\right)\right]: \delta 184.2,172.1$, 150.4, 126.6, 67.3 and 43.4. HRMS (70 eV, $\mathrm{m} / \mathrm{z})$ : calcd. for $\mathrm{C}_{8} \mathrm{H}_{9} \mathrm{NO}_{3}$ - $\mathrm{M}^{\circ+}, 167.05824$; found: 167.04752 .

\section{(+/-)-3-Bromoverongiaquinol (1)}

A soln. of silyl amide $5(0.022 \mathrm{~g}, 0.09 \mathrm{mmol})$ in acetonitrile $(0.80$ $\mathrm{mL}$ ) was cooled to $0{ }^{\circ} \mathrm{C}$ when a $0.1 \mathrm{M}$ soln. of bromine in $\mathrm{CHCl}_{3}$ $(0.90 \mathrm{~mL}, 0.090 \mathrm{mmol})$ was added. The reaction mixture was stirred at $\mathrm{rt}$ for $30 \mathrm{~min}$ and the solvent was removed under reduced pressure. The crude product was purified by column chromatography on silica gel (ethyl acetate as eluent) to afford (+/-)-1 (0.019 g, $0.08 \mathrm{mmol})$ in $89 \%$ yield as a yellowish oil. An analogous procedure provided (+/-)-1 from amide (+/-)-6. IR (film, $\left.\mathrm{cm}^{-1}\right)$ : 3348, 1668, 1406, 1030, 964 and 827.

${ }^{1} \mathrm{H}-\mathrm{NMR}\left[500 \mathrm{MHz},\left(\mathrm{CD}_{3}\right)_{2} \mathrm{CO}\right]: \delta 7.56(1 \mathrm{H}, \mathrm{d}, J 2.6 \mathrm{~Hz}), 7.20$ $(1 \mathrm{H}$, br s), $7.12(1 \mathrm{H}, \mathrm{dd}, J 10.1$ and $2.7 \mathrm{~Hz}), 6.70(1 \mathrm{H}, \mathrm{br} \mathrm{s}), 6.25$ $(1 \mathrm{H}, \mathrm{d}, J 10.1 \mathrm{~Hz}), 5.96(1 \mathrm{H}, \mathrm{s})$ and $2.71(2 \mathrm{H}, \mathrm{d}, J 1.1 \mathrm{~Hz}) .{ }^{13} \mathrm{C}-\mathrm{NMR}$ [125 MHz, $\left.\left.\left(\mathrm{CD}_{3}\right)_{2} \mathrm{CO}\right)\right]: \delta 178.1,172.1,151.9,151.8,125.8,123.5$, 71.0 and 43.9. HRMS (70 eV, $\mathrm{m} / z$ ): calcd. for $\mathrm{C}_{8} \mathrm{H}_{8} \mathrm{NO}_{3} \mathrm{Br}-\mathrm{M}^{\cdot+}$, 244.96876; found: 244.96901

\section{(+/-)-5-monobromocavernicolin (2) and 7-Bromo-3a-hydroxy- 2,3,3a,6,7,7a-hexahydro-1H-2,6-indoledione (8)}

Method A: To a soln. of (+/-)-5 (0.015 g, $0.06 \mathrm{mmol})$ in acetonitrile $(0.80 \mathrm{~mL})$ cooled to $0{ }^{\circ} \mathrm{C}$ was added dropwise a $0.1 \mathrm{M}$ soln of bromine in $\mathrm{CHCl}_{3}(0.60 \mathrm{~mL}, 0.06 \mathrm{mmol})$. The reaction mixture was let to stir $30 \mathrm{~min}$ at $\mathrm{rt}$ when the solvent was removed under reduced pressure to provide a brown solid residue, which was dissolved in $\mathrm{CH}_{3} \mathrm{CN}(6.0 \mathrm{~mL})$ and treated with $\mathrm{DBU}(9.0 \mu \mathrm{L}, 0.06 \mathrm{mmol})$. After stirring $12 \mathrm{~h}$ at rt, a satd. soln. of $\mathrm{NH}_{4} \mathrm{Cl}$ was added, the mixture was dried over $\mathrm{MgSO}_{4}$ and the solvent was removed under reduced pressure. The residue was purified by column chromatography on silica gel (1:9 hexanes/ethyl acetate as eluent) to afford (+/-)-2 (2.9 $\mathrm{mg}, 0.012 \mathrm{mmol}$ ) in $20 \%$ yield as a colorless solid ( $\left.\mathrm{mp} 184-185^{\circ} \mathrm{C}\right)$ together with (+/-)-1 (6.8 mg, $0.028 \mathrm{mmol})$ and (+/-)-8 $(1.4 \mathrm{mg}$, $\left.5.7 \times 10^{-3} \mathrm{mmol}\right)$.

Method B: To a soln. of (+/-)-1 (6.8 mg, $0.028 \mathrm{mmol})$ in acetonitrile $(3.0 \mathrm{~mL})$ was added DBU $(4.2 \mu \mathrm{L}, 0.028 \mathrm{mmol})$. After stirring $12 \mathrm{~h}$ at rt, a satd. soln. of $\mathrm{NH}_{4} \mathrm{Cl}$ was added and the mixture was treated with anhydrous $\mathrm{MgSO}_{4}$. The solvent was removed under reduced pressure and the residue was purified by column chromatography on silica gel (1:9 hexanes/ethyl acetate as eluent) to afford (+/-)-2 (0.9 mg, 3.7 $\left.\mathrm{x} 10^{-3} \mathrm{mmol}\right)$ in $13 \%$ yield [ $25 \%$ yield based on recovered $(+/-)-1$ ] as a colorless solid and (+/-)-8 (1.6 mg, $\left.6.5 \times 10^{-3} \mathrm{mmol}\right)$ in $23 \%$ yield.
Analytical data for (+/-)-5-monobromocavernicolin (2): IR (neat, $\left.\mathrm{cm}^{-1}\right): 3438,2922,2852,1689,1410,1331,1051,1026,1001,825$ and 764. ${ }^{1} \mathrm{H}-\mathrm{NMR}\left[300 \mathrm{MHz},\left(\mathrm{CD}_{3}\right)_{2} \mathrm{CO}\right]: \delta 7.29(1 \mathrm{H}, \mathrm{br} \mathrm{s}), 7.09(1 \mathrm{H}, \mathrm{br}$ s), $5.38(1 \mathrm{H}$, br s), $4.14(1 \mathrm{H}$, br t), $3.04(1 \mathrm{H}, \mathrm{dd}, J 16.4$ and $4.8 \mathrm{~Hz})$, $2.68(1 \mathrm{H}, \mathrm{d}, J 16.7 \mathrm{~Hz})$ and $2.58(1 \mathrm{H}, \mathrm{d}, J 16.7 \mathrm{~Hz}) .{ }^{1} \mathrm{H}-\mathrm{NMR}[500$ $\mathrm{MHz}, \mathrm{CD}_{3} \mathrm{OD}$ ]: $\delta 7.27$ (1H, br s), 4.08 (1H, br t), 3.05 (1H, dd, J 16.5 and $4.7 \mathrm{~Hz}), 2.82(1 \mathrm{H}, \mathrm{dd}, J 16.5$ and $6.4 \mathrm{~Hz}), 2.75(1 \mathrm{H}, \mathrm{d}, J 17.0$ $\mathrm{Hz})$ and $\left.2.68(1 \mathrm{H}, \mathrm{d}, J 17.0 \mathrm{~Hz}) .{ }^{1} \mathrm{H}-\mathrm{NMR}\left[500 \mathrm{MHz},\left(\mathrm{CD}_{3}\right)_{2} \mathrm{SO}\right)\right]: \delta$ 7.95 (1H, br s), 7.28 (1H, br s), 6.28 (1H, br s), 3.88 (1H, br t), 2.92 $(1 \mathrm{H}, \mathrm{dd}, J 16.2$ and $4.3 \mathrm{~Hz}), 2.71(1 \mathrm{H}, \mathrm{dd}, J 16.8$ and $6.1 \mathrm{~Hz}), 2.60$ $\left(1 \mathrm{H}, \mathrm{d}, J 16.5 \mathrm{~Hz}\right.$ ) and $2.45(1 \mathrm{H}, \mathrm{d}, J 16.5 \mathrm{~Hz}) .{ }^{13} \mathrm{C}-\mathrm{NMR}[125 \mathrm{MHz}$, $\left.\mathrm{CD}_{3} \mathrm{OD}\right]: \delta 190.7,177.1,150.7,125.5,76.4,61.9,45.6$ and 41.6. $\left.{ }^{13} \mathrm{C}-\mathrm{NMR}\left[125 \mathrm{MHz},\left(\mathrm{CD}_{3}\right)_{2} \mathrm{SO}\right)\right]: \delta 189.0,172.8,150.1,122.5,74.2$, 58.7, 43.7 and 39.8. HRMS (ESI, $m / z$ ): calcd. for $\mathrm{C}_{8} \mathrm{H}_{9} \mathrm{NO}_{3} \mathrm{Br}-\mathrm{MH}^{+}$, 245.9766; found: 245.9742 .

Analytical data for 7-Bromo-3a-hydroxy-2,3,3a,6,7,7a-hexahydro-1H-2,6-indoledione (8): IR (film, $\mathrm{cm}^{-1}$ ): 3269, 2979, 2925 , 1685, 1396, 1244, 1097 and 1049. ${ }^{1} \mathrm{H}-\mathrm{NMR}\left(300 \mathrm{MHz},\left(\mathrm{CD}_{3}\right)_{2} \mathrm{CO}\right)$ : $\delta[7.71(\mathrm{br} \mathrm{s})$ and $7.23(\mathrm{br} \mathrm{s}) 1 \mathrm{H}], 7.01(\mathrm{~d}, J 10.3 \mathrm{~Hz})$ and $6.88(\mathrm{~d}$, $J 10.3 \mathrm{~Hz}), 1 \mathrm{H}],[6.16(\mathrm{~d}, J 10.3 \mathrm{~Hz})$ and $6.11(\mathrm{~d}, J 10.3 \mathrm{~Hz}) 1 \mathrm{H}]$, [5.42 (br s) and $5.33(\mathrm{br} \mathrm{s}), 1 \mathrm{H}],[5.12(\mathrm{~d}, J 4.0 \mathrm{~Hz})$ and $5.08(\mathrm{~d}, J 9.9$ $\mathrm{Hz}), 1 \mathrm{H}],[4.42(\mathrm{br} \mathrm{d}, J 4.0 \mathrm{~Hz})$ and $4.16(\mathrm{dd}, J 10.1$ and $1.5 \mathrm{~Hz}) 1 \mathrm{H}$ ], $[2.87(\mathrm{~d}, J 16.8 \mathrm{~Hz})$ and $2.70(\mathrm{~d}, J 16.8 \mathrm{~Hz}), 1 \mathrm{H}]$ and $[2.61(\mathrm{~d}, J 16.8$ $\mathrm{Hz})$ and $\left.2.47(\mathrm{~d}, J 16.8 \mathrm{~Hz}), 1 \mathrm{H}] .{ }^{13} \mathrm{C}-\mathrm{NMR}\left[75 \mathrm{MHz},\left(\mathrm{CD}_{3}\right)_{2} \mathrm{CO}\right)\right]$ : $\delta 190.0,189.5,173.8,173.5,149.7,148.7,125.8,125.7,75.0,73.5$, $69.6,65.2,58.5,54.3,45.4$ and 43.5 .

\section{CONCLUSIONS}

In this work, we have described the preparation of (+/-)-3-bromoverongiaquinol (1) in 50\% overall yield from 1,4-benzoquinone (3), a more efficient approach than the one previously described in the literature. The first total synthesis of (+/-)-5-monobromocavernicolin (2) in $11 \%$ overall yield from 1,4-benzoquinone (3) was also described, thus confirming the relative configuration assigned by Pietra and coworkers. Additionally, it was demonstrated that 5-monobromocavernicolin (2) can be prepared in 13\% yield (or 25\% based on recovered starting material) from 3-bromoverongiaquinol (1) giving support to a conceivable biogenetic origin of (+/-)-2 from (+/-)-1.

\section{ACKNOWLEDGEMENTS}

The authors would like to thank FAPESP (Fundação de Amparo à Pesquisa no Estado de São Paulo) for the financial support and fellowship and CNPq (Conselho Nacional de Desenvolvimento Científico e Tecnológico) for the research fellowship.

\section{REFERENCES}

1. Kelecom, A.; An. Acad. Bras. Cienc. 1999, 71, 249; Berlabi, E.; Gomez, A. C.; Chisti, Y.; Camacho, F. G.; Grima, E. M.; Biotechnol. Adv. 2003, 21, 585; Mayer, A. M. S.; Rodríguez, A. D.; Berlinck, R. G. S.; Hamann, M. T.; Biochim. Biophys. Acta-Gen. Subj. 2009, 1790, 283.

2. Sipkema, D.; Franssen, M. C. R.; Osinga, R.; Tramper, J.; Wijffels, R. H.; Mar. Biotechnol. 2005, 7, 142; Thoms, C.; Horn, M.; Wagner, M.; Hentschel, U.; Proksch, P.; Mar. Biol. 2003, 142, 685.

3. Walkup, R. D.; Jamieson, G. C.; Ratcliff, M. R.; Djerassi, C.; Lipids 1981, 16, 631 .

4. Ayanoglu, E.; Djerassi, C.; Erdman, T. R.; Scheuer, P. J.; Steroids 1978, 31,815 .

5. Hertzberg, S.; Ramdahl, T.; Johasen, J. E.; Liaaen-Jensen, S.; Acta. Chem. Scand. Ser. B 1983, 37, 267.

6. Wagner, I.; Musso, H.; Angew. Chem., Int. Ed. 1983, 22, 816. 
7. D’Ambrosio; M.; Guerriero, A.; Pietra, F.; Helv. Chim. Acta 1984, 67, 1484.

8. Guerriero, A.; D'Ambrosio; M.; Traldi, P.; Pietra, F.; Naturwissenschaften 1984, 71, 425.

9. Kijjoa, A.; Watanadilok, R.; Sonchaeng, P.; Sawangwong, P.; Pedro, M.; Nascimento, M. S. J.; Silva, A. M. S.; Eaton, G.; Herz, W.; Z. Naturforsch. C 2002, 57, 732 .
10. Bicchierini, N.; Cavazza, M.; Nucci, L.; Pergola, F.; Pietra, F.; Tetrahedron Lett. 1991, 32, 4039.

11. Evans, D. A.; Wong, R. Y.; J. Org. Chem. 1977, 42, 350.

12. Hong, S.; Mclntosh, M. C.; Org. Lett. 2002, 4, 19; Smith III, A. B.; Branca, S. J.; Pilla, N. N.; Guaciaro, M. A.; J. Org. Chem. 1982, 47, 1855. 